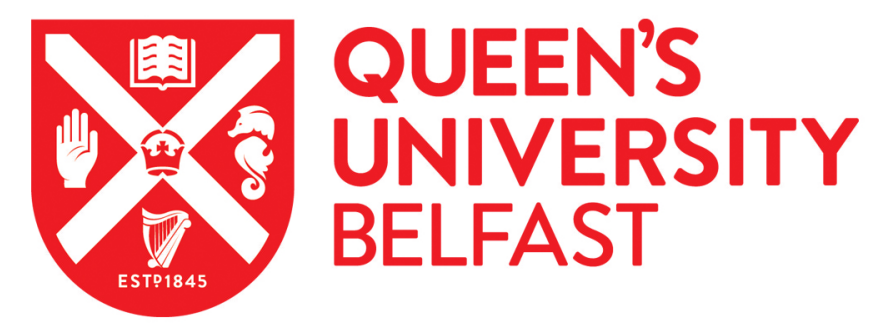

\title{
The EU's Peace and Security Narrative: Views from EU Strategic Partners in Asia
}

Chaban, N., Miskimmon, A., \& O'Loughlin, B. (2017). The EU's Peace and Security Narrative: Views from EU Strategic Partners in Asia. Journal of Common Market Studies, 55(6), 1273-1289.

https://doi.org/10.1111/jcms.12569

Published in:

Journal of Common Market Studies

Document Version:

Peer reviewed version

Queen's University Belfast - Research Portal:

Link to publication record in Queen's University Belfast Research Portal

Publisher rights

(c) 2017 University Association for Contemporary European Studies and John Wiley \& Sons Ltd. This work is made available online in accordance with the publisher's policies. Please refer to any applicable terms of use of the publisher.

\section{General rights}

Copyright for the publications made accessible via the Queen's University Belfast Research Portal is retained by the author(s) and / or other copyright owners and it is a condition of accessing these publications that users recognise and abide by the legal requirements associated with these rights.

Take down policy

The Research Portal is Queen's institutional repository that provides access to Queen's research output. Every effort has been made to ensure that content in the Research Portal does not infringe any person's rights, or applicable UK laws. If you discover content in the Research Portal that you believe breaches copyright or violates any law, please contact openaccess@qub.ac.uk. 


\title{
The EU's Peace and Security Narrative: Views from EU Strategic Partners in Asia
}

\author{
Natalia Chaban, Alister Miskimmon and Ben O'Loughlin'1 \\ Published as: Chaban, Natalia, Alister Miskimmon, and Ben O'Loughlin. "The EU's Peace and \\ Security Narrative: Views from EU Strategic Partners in Asia." JCMS: Journal of Common Market \\ Studies 55, no. 6 (2017): 1273-1289.
}

\begin{abstract}
The EU has consistently struggled to forge a foreign policy narrative which promotes internal cohesion and supports the EU's efforts to exert international influence. The 2016 EU Global Strategy is the latest iteration of collective efforts to tie strategy and purpose to the EU's coherent identity in the world. This study compares the EU's strategic narrative of peace and security with narratives about the EU, held in the EU's Strategic Partners in Asia. Whilst we find reasonable coherence in the EU's projection of the international system and its role in it, its identity as an actor, and its response to policy issues on the ground, views from Asia largely contest these claims. This article employs a strategic narrative approach to conceptualise and empirically trace how the formation, projection and reception of EU narratives are part of broader circuits of communication through which EU might be recognised, legitimised, and achieve influence.
\end{abstract}

\section{INTRODUCTION}

In a recent article in this journal, Manners and Murray called for a renewed emphasis on research on narratives and the EU. They argue:

Research pathways could usefully develop an examination of how, and by whom, many of the EU narratives are formulated; why and when they are projected; and how they are perceived by their recipients, both within the EU and in an international context. (Manners and Murray, 2016, p.199)

We aim to show how the research trajectory outlined by Manners and Murray can be developed. Narrative analysis makes an important contribution to the study of the EU because, as a political and economic entity, the EU is still in the process of emerging, with no clear agreement on what final form it should take (Della Sala, 2010; Lacroix and Nicolaidis, 2010). Narratives are central to this process.

Strategic narratives are 'a means for political actors to construct a shared meaning of the past, present and future of international politics to shape the behaviour of domestic and international actors (Miskimmon et al., 2013, p.2). Narratives are meaning created through representation of a time sequence, causally relating separate events, with a pastpresent-future structure, and indication of possible resolutions (Shenhav, 2006). Burke (1957) identifies five components of any narrative: characters or agents; a setting, environment or scene; a conflict or action; tools and behaviour actors use to address it; and a resolution. We highlight narratives about the international system outlining how actors view the international order; narratives deployed by political actors to influence

\footnotetext{
${ }^{1}$ The authors wish to thank the generosity of the Jean Monnet Lifelong Learning Programme which supported the 2010-12 project studying EU perceptions in Asia-Pacific cited in this article
} 
specific issues; and identity narratives projected by a political actor to influence international affairs. Alignment between system, policy and identity narratives increases opportunities for persuasion and influence.

Fundamental to the analysis of strategic narratives are the linked processes of narrative formation, projection and reception (Miskimmon et al., 2013). Reception concerns how narratives are received, interpreted, and become meaningful to audiences - elites or publics. Reception can be approached in terms of reach or saturation, how individuals understand and process information, the affective responses narratives generate, and particularly in a digital age - how audiences recirculate, remediate and remix the narrative content. Reception happens in situated contexts where narratives may be discussed socially as well as processed individually, and where cultural filters conditions degrees of openness or dogmatism in responses to new or challenging narratives (Björkdahl et al., 2015). Reception depends on the availability of specific media or services, and each medium offers different possibilities for communicating back (Miskimmon et al., 2017). This occurs within a complex media ecology which shapes, distorts, disrupts but ultimately enables communication of strategic narratives. It allows alternative voices and marginalized actors to challenge dominant narratives, while affording opportunity for the powerful to project narratives in new ways.

We explore the complexity of projecting an external narrative of the EU and address Manners and Murray's example of the response to the awarding of the 2012 Nobel Peace Prize to the EU by examining how the EU was received and understood among Asian audiences. Manners and Murray indicate how incongruous the EU's award seemed. Our study seeks to explain how this process works. We ask: Do outsiders recognise the EU as a producer of a peace and security narrative? On what level - system, identity or issue specific? What components of the narrative are recognized outside the EU? We consider 'cultural filters' of EU external perceptions and their role in the reception mechanism postulated by the strategic narrative theory. Perceptions form the basis for external recognition as key indicators of the EU's successful global influence.

Strategic narratives are conceptualized as a 'tool for political actors to extend their influence, manage expectations, and change the discursive environments in which they operate' (Miskimmon et al., 2013, p.2). Strategic narrative research focuses on the strategy and intent of the communicating actor. It identifies points of convergence or divergence in the narratives through which audiences understand international politics. Our contribution to this scholarly and practitioner debate about EU communication and influence focuses on the narratives projected by the EU and understood by audiences in the EU's Asian strategic partners and how this explains external recognition of the EU in the area of peace and security.

We argue that understanding of already existing narratives - projected and received - is critical for analysing Asia's reactions to the new 2016 EU Global Strategy and EU actions following it. "Security" and "Asia" are a firm association in the Strategy's projected narrative. The document first mentions Asia in the context of 'security tensions' (EUGS, 2016, p.7) that are later described as 'mounting' (ibid., p.13). In a special section "Connected Asia", the document states, "There is a direct connection between European prosperity and Asian security. In light of the economic weight that Asia represents for the EU, and vice versa, peace and stability in Asia are a prerequisite for our prosperity. We 
will deepen economic diplomacy and scale up our security role in Asia' (ibid., p.37). To address growing security concerns in Asia, the EU also declares that it will 'develop a more politically rounded approach to Asia, seeking to make greater practical contributions to Asian security' (ibid., p.38).

The EUGS specifically mentions China, Japan, South Korean and India, four countries in our focus. Both economic and security relations are mentioned for all them. The EU promises to 'expand our partnerships, including on security, with Japan, the Republic of Korea' and 'promote non-proliferation in the Korean peninsula' (ibid., p.38). East (and South East) Asia are regions where the EU intends to 'uphold freedom of navigation, stand firm on the respect for international law, including the Law of the Sea and its arbitration procedures, and encourage the peaceful settlement of maritime disputes. We will help build maritime capacities and support an ASEAN-led regional security architecture' (ibid., p.38). South Asia is an area where the EU plans to 'deepen cooperation on counterterrorism, anti-trafficking and migration...' (ibid., p.38).

This analysis rests on the assumption that the, 'reputation, the reflection of the reality of power in the mind of the observers can be as important as the reality of power itself. What others think about us is as important as what we actually are' (Morgenthau, 1965, p.73). Analysis of external images helps 'evaluate whether gaps between expectations and realities have affected the "reach" of EU influence' (Rhodes, 1998, p.6). The AsiaPacific is increasingly confident in international political arenas, economically dynamic and enjoys long-standing links with the US in the security field. Whilst the US is already recognised in the Asia-Pacific region as an influential security actor, the EU's role remains ill-defined. Some commentators argue the EU's influence on Asian security issues remains marginal, with the dominant dyad being viewed in Beijing as the G-2 (Zeng and Breslin, 2016; Tsuruoka, 2011).

These four Asian countries generate their own images and narratives of the EU, rather than accepting those projected from Brussels. We test this through thematic analysis of the Lisbon Treaty text and of elite opinion interview responses in the four Asian countries $(\mathrm{n}=180$ face-to-face semi-structured interviews undertaken in 2012). The analysis reveals that whilst the EU's peace and security narratives projected internationally are recognised, they are often interpreted differently in different locations, mediated in each location by a complex and unique set of factors, motivations and values. We outline a systematic account of divergence and convergence between self-projected and externally-received narratives as a tool to advance the EU's informed dialogue with the world; a shift of horizon from EU transmission of narratives towards the processes of narrative negotiation and the broader processes of persuasion and power stressed by EU Global Strategy.

\section{ANALYTICAL FRAMEWORK}

Manners and Murray (2016) identify six competing narratives that show sense-making inside and outside EU institutions about Europe's past, present and future, arguing the formation of narratives by non-EU actors has implications for the EU's legitimation. Strategic narrative analysis goes further by going beyond textual analysis of formation and projection to deploy methods to identify practices of reception. Whilst Manners and Murray express an interest in the 'process of legitimation' (ibid., p.187), we understand legitimation as a negotiated, relational process depending on the generation of public 
consent. It cannot be identified from the policy texts themselves. Methods must be chosen that generate data allowing for identification and explanation of perceptions to identify how publics respond to those narratives, if at all. This matters because the case they highlight - reactions to the EU's 2012 Noble Prize Peace award - provocatively suggests that the post-World War II peace narrative is outdated, requiring a new, compelling EU narrative. Integrating narrative formation, projection and reception, strategic narrative analysis allows for tracing and evaluating the circuits of communication involved in legitimation, as well as authorization and persuasion.

These circuits go beyond European space and voices. The contemporary revision of Europe's peace and security narrative is again happening from a Euro-centric perspective through the EU's response to the Ukraine and migrant crises. We challenge this approach and extend the debate by considering how the EU's self-image and narratives resonate with external images and narratives. Convergence and divergence between the projected and received images are meaningful for the EU as it strives to be a leading global actor in peace and security. We approach communication as sense-making: not as linear transmission of information, but as a qualitative, interpretive process with cognitive and affective dimensions. We do not analyse communication as a matter of the EU "getting its message across" and instead provide a framework for a richer understanding of communication in EU diplomacy.

External images and perceptions constitute a primary filter of EU narratives. Therefore, it is important to examine how perceptions of the EU's position feed into existing debates in 3rd countries and the long-standing cultural assumptions and practices therein. Research employing Kinnvall's concept of cultural filters highlights the complexity of reception of EU narratives by third parties, especially when a norm or a value is projected (and according to the Normative Power Europe conceptualisation, peace is one of the EU's norms) (Björkdahl et al., 2015; Pardo, 2015). For Kinnvall, a cultural filter 'affects the impact of international norms and political learning in third states and organizations leading to learning, adaptation or rejection of norms' (Kinnvall, 1995, pp.61-71). For Manners, cultural filters are to be 'based on the interplay between the construction of knowledge and the creation of social and political identity by the subjects of norm diffusion' (Manners, 2002, p.245). Critical long-term systematic accounts of EU perceptions among non-EU states cast light on the range of external reactions to EU narratives, from adoption and adaption to resistance and rejection (Björkdahl et al., 2015). It is important to explain how processes of influence work to the EU's cost or benefit. It is at this analytic intersection that we seek to capture the complexities of the external reception of the EU's narrative among Asian strategic partners each with their own societal and individual cultural filters.

The EU's peace narrative has arguably been an attractive 'story' about post-World War II Europe, before morphing into a peace and security narrative in the post-Cold War era as the EU shifted from a security consumer to producer, outlined in both the Lisbon Treaty and 2016 EU Global Strategy. Overcoming centuries of bloody conflicts, the European Community created conditions making it unthinkable that Member States would use force against one another. Following World War II, this narrative was projected and received as achievable and normatively desirable both internally and externally (Garton Ash, 2012). The emergence of the EU's security narrative accompanied the development of the Common Foreign and Security Policy (CFSP) post-1993, but becomes much more 
explicit after the Kosovo conflict with the EU's move to develop autonomous military capabilities outside of NATO. The EU's security narrative needed to be linked to its preexisting peace narrative to avoid internal identity conflicts within the EU between neutral and aligned states, and those more extrovert and introverted military actors (Heisbourg, 2001).

Reflecting on the mixed internal and external reactions to the 2012 Nobel Prize for Peace awarded to the EU, other observers (Manners and Murray, 2016) propose different narratives as more viable and appealing. They consider alternative narratives (e.g. 'fortress Europe'), or forgotten ones (e.g. 'social Europe', 'green Europe', 'Single Market Europe') or critical ones (e.g. 'neo-liberal Europe', 'civilization Europe'). Kaldor et al. (2007) suggest 'human rights Europe' and 'regional integration Europe' as strategic narratives which may hold greater appeal than the peace narrative. This menu of narratives indicates how, by this time, the EU sought to play the role of traditional and non-traditional security producer both in its neighbourhood and further afield. Consequently, our analysis of EU external perceptions may illuminate which strategic narratives projected by the EU achieve global resonance.

\section{STUDYING EU PERCEPTIONS IN ASIA}

The study of EU external images is a vibrant area of enquiry (Lucarelli, 2014; Chaban and Holland, 2014, 2015; Elgström and Chaban, 2015). EU images in Asia, particularly in China and Japan, were considered in a pioneering collection by Ortega (2004). A major "EU Global Perceptions" project explores EU public, elite and media perceptions in 12 Asian countries (Chaban and Holland, 2014, 2015). In 2015, a project focused on EU perceptions in ten EU Strategic Partners (PPMI/NCRE/NFG, 2015). China, India and Japan were studied by Lucarelli and Fioramonti (2009), with China and India also prominent in "Asian Perceptions of the EU" (Stumbaum et al., 2015) and "EuroBroadMap" (online). EU perceptions have been studied in the cases of China (Shambaugh et al., 2008; Zhang, 2011; Lisbonne-De Vergeron 2007, 2011; Zhou, 2007; "Disaggregating EU Perceptions", online), Japan (Tsuruoka 2008; Oshiba 2012), Korea (Park and Yoon, 2008, 2015) and India (Jain and Pandey, 2008, 2010; Lisbon-De Vergeron, 2006, 2011).

Findings consistently reported that Asia sees the US, not the EU, as a leading security actor. The EU's 'storyline' in Asia casts the EU into a primarily economic role. In the early 2000 s, it was seen as a strong actor, able to hurt others through its protectionist policies. Since the Eurozone crisis, it has been seen as a weakened, struggling economic actor. Importantly, the EU's economic ills were not seen as contagious for Asia. The EU is increasingly seen in Asia as falling behind not only the US but also a new cohort of 'emerging powers', particularly China.

Another narrative traced through the perceptions literature on Asia focuses on the EU's unique supranational design and identity. Pre-Brexit studies in Asia indicated perceptions of the EU as a successful model of regional integration. In contrast, the EU's internal divides have been seen to undermine the EU's qualities of an international leader. Despite the recent EU image of a divided whole in its many crises, opinion in the region (and specifically general public opinion) remains positive - the EU continues to be seen in Asia as a desired international leader (PPMI/NCRE/NFG, 2015). The EU's most positive images presented by Asian media and reflected upon by Asian publics are images in the context of environment, energy, research/science/technology, development, 
cultural activities and education. However, the two most visible issues are political and socio-economic ones that have acquired increasing negative connotations, and heightened visibility, in media and among elites and publics due to the EU's recent political, economic and social crises.

Another 'story' of the EU in perception research is that of Europe possessing certain values and norms, with peace as one norm. These perceptions reveal a complicated image of the EU. In this story, the EU is imagined as rather "Eurocentric", an actor who often "talks at" rather than "talks with" its counterparts in Asia, ignoring the values communicated by Asian actors. In addition, the migration crisis exposed the EU to Asian media as violating its core values when dealing with the refugees (PPMI/NCRE/NGF, 2015). These three storylines indicate respectively the existing, albeit broad, issue, system, and identity narratives of the EU in Asia.

\section{Theory and methods in researching EU perceptions}

Our analysis expands on the narratives indicated above. Despite diverse approaches and case studies, research into perceptions of the EU's foundational narrative on peace is nonexistent. Whilst security is a popular dimension in EU perceptions research in Asia, such views have never been explored through strategic narrative. In this section we outline how the study theorises the reception of strategic narratives through the phenomenon of cultural filters.

Three clusters of explanations elaborated in large-scale empirical studies (PPMI/NCRE/NFG, 2015; Chaban and Magdalina, 2014) are elaborated further here systemic (geopolitical and economic global trends); socio-cultural (political/media systems, historical, cultural and linguistic conditions; value systems); and demographic (personal/professional contacts with Europe/EU, levels of education and information about Europe/EU, age, region). The complex interaction of these factors is further refracted through self-perceptions in relation to the imagined Other. This complexity demonstrates EU perceptions are location-specific. Whilst some indicators could be similar (e.g. two countries are democracies), other indicators are necessarily different, making explanation of perceptions a complex task. The unique combination of factors, modified by self-perceptions, creates a culture-specific filter for perceptions of the Other. While we do not seek to explain the particular narratives held by individual respondents, accounting for cultural filters illuminates why certain responses are more likely. This paves the way for future research explaining how and why certain individuals negotiate their own narratives of international affairs when confronted by narratives projected by others, including the EU.

This study of EU strategic narrative(s) begins with analysis of projection, here in the text of the Treaty of Lisbon (2009), focusing on how the concepts of 'peace' and 'security' are represented by the Treaty. An exclusive focus on the Treaty's text is deliberate. The Treaty reintroduced the EU as an actor aspiring to be a global leader in an increasingly multipolar world. Asian commentators recognised the Treaty as setting a 'trajectory that enables its global neighbours, partners and antagonists to start taking Europe seriously' (Mishra, 2009). Consequently, narratives projected by the EU through the Treaty of Lisbon, an EU foundational document, possess a higher visibility and potential influence in informing both internal and external reception of the EU's communications. Three 
levels of the narrative underpin the following analysis of the projection: system, identity and issue narratives.

We investigate the element of external reception through opinions held by Asian elites members of given societies who are in positions to make decisions having major consequence' (Mills, 1956, p.3). This analysis continues an established tradition in the research of EU external perceptions focused on elite opinion. National elites in each country from four cohorts were interviewed: political leaders (parliamentarians and officials from government ministries), business leaders (major exporters, members of Chambers of Commerce/national Business Roundtables, leading financiers), representatives of civil society organisations (national, international), and media personalities (journalists, editors). Face-to-face semi-structured interviews - 180 in total - took place in China (60 interviews), India (40), Japan (40) and South Korea (40) in 2012. Following Mill's definition, these elites are chosen for analysis as 'they occupy the strategic command posts of the social structure, in which are now centred the effective means of the power and the wealth and the celebrity which they enjoy' (ibid.).

Importantly, the questionnaire (identical in the four countries to ensure cross-country comparison) was not "security-specific". It was designed to identify general EU external perceptions: in terms of the EU's perceived global power and international leadership, importance for and relations with the location, and its issue-specific perceptions (e.g. EU enlargement, the euro). This study analysed answers to the questionnaire using three key search terms - 'peace', 'war' and 'security' - and traced peace and security narratives that emerged when elites express their spontaneous views on the EU. We first analysed the five narrative components (see above): actors, setting, conflict, instrument for action, and resolution. Second, the three levels of the narrative once again guided the analysis of EU images - the system, identity and issue narratives. We then compared the narratives projected vis-à-vis how the narratives are received and interpreted. This approach is intentionally qualitative - it is the richness of the narration on an individual level that is our focus. ${ }^{\text {ii }}$ Whilst 180 interviews considered here present a sufficient sample to engage quantitatively, a quantitative approach would not achieve our research objectives. These are to ascertain whether or not Asian actors do have narratives on the EU as a peace and security actor; trace which elements and levels resonate between projected and received narratives; and discuss the meaning of the convergence and divergence between projected and received narratives for the EU's dialogue with its strategic partners in Asia.

\section{PROJECTION AND RECEPTION OF EU PEACE AND SECURITY NARRATIVES EU self-narrative}

The Treaty of Lisbon emerged from almost a decade-long negotiation by EU Member States on reforming the EU post-enlargement and as a response to the shifting regional and global contexts. We trace how the five components of narratives are projected. The Treaty represents the EU as a supranational international actor whose actions take place in two settings - internal (across the EU Member States) and external (either in EU neighbourhood or far from its borders). Internally, the EU will 'promote peace, its values and the well-being of its peoples' (Article 3, point 1); externally, the EU will 'preserve peace, prevent conflicts and strengthen international security in accordance with the UN Charter' (Article 21.1.c). The intentions of those actions are formulated from a normative standpoint - the Treaty sets the EU's external actions to, 'reinforc[e] the European identity and its independence in order to promote peace, security and progress in Europe 
and in the world' and 'safeguard its values, fundamental interests, security, independence and integrity' (Article 2.1.1.a.). Values driving the EU's external actions, including in the areas of peace and security, are 'democracy, the rule of law, human rights and the principles of international law' (Article 2.1.1.b.), as well as 'sustainable economic, social and environmental development' (Article 2.1.1.d) and 'the integration of all countries into the world economy' (Article 2.1.1.e).

The Treaty projects a peace and security narrative on the three levels. Firstly, it frames the EU on the level of the system narrative based on values and interests upheld by international law (Article 8.1). The EU is an agent of peace, security and progress in Europe and globally, possessing actorness and recognition from and among other equivalent actors. Regarding issue narrative, when dealing with the wider world, peacekeeping, peace-making and post-conflict stabilisation were the most visible issues (Articles 42 and 43). Yet, those two levels did not dominate the EU's projections. The most visible type of narrative projected by the Treaty is the identity narrative; formulations of the actions of the EU as a peace and security actor in various settings are guided by a set of distinct norms. Importantly, in the Treaty's formulation, the normative position prominent on the identity level informs the two other narrative levels (Article 3.5). Being a normative peace and security actor entails supporting a certain kind of international system that can act on those values and it entails dealing with specific manifestations of insecurity. This demonstrates how different narrative levels can bring coherence to the overall projection.

\section{External Reception}

Perceptions of the EU revealed that there is much commonality in the 'story' of the EU as a peace and security actor across the four locations and three narrative levels. This reveals a discernible geo-political (Asian) perspective. Commonalities were largely observed on the system and issue levels. Most of the differences were noted at the level of identity narrative.

\section{System narrative}

This analysis found an array of perceptions of the EU as an actor for peace and security on the system level. Elites in the four countries demonstrated a shared a vision of the EU as an actor in the area of peace and security. Yet, the EU's actions were recognized to be of lesser relevance and importance to respondents in the four locations than those of the US, Asian neighbours and even the EU's own Member States. The EU was often understood as a weaker peace and security actor compared to the aforementioned players. External elite opinion indicated little is expected of the EU, nor is it perceived to hold a leadership role.

In all four locations, the US was seen as the primary global peace and security actor, largely due to its bi-lateral relations with each country in this study. In Japan, whilst both the US and EU were seen a geographically distant, in the security field US-Japan relations were 'very important' (civil society representative) iii and 'special' (politician). The US is seen in Japan as 'security provider' (politician) and 'priority' (media), yet 'the EU is never a counterpart in that regard - for hard security' (politician). An Indian newsmaker noted that in matters of security Europe 'always looked upon Washington as its leader...it [the EU] did not play a leadership role'. A Chinese businessperson echoed: 'Europe, or the EU has always tried to become a leading force, but failed...Europe has to rely on the US on 
many issues, including providing security protection to the EU'. A Korean civil society representative stated, 'The US is crucial to Korea both in security and economy' and 'the issues related to the EU [are of less] importance to Korea[...] since the American President directly affects Korean economy and security, while European countries have less effect in these fields'.

Asian states and Asian security cooperation institutions are seen as important actors in the area of peace and security. Predictably, regional geopolitical concerns guide this perception. A Japanese politician compared the perceived importance of various actors: 'for...peace and security...Asia, especially North-East Asia is by far the most important region because that is the area that surrounds us'. For a Chinese businessperson, 'From the military and security side, Japan and Southeast Asia are the most important for China in Asia'. For an Indian newsmaker, South Asia has 'far too many...security and political contradictions'.

Finally, the EU is seen as overshadowed by its powerful Member States. The fact that several EU Member States are also members of the UN Security Council was mentioned by many respondents in the four locations. In contrast to the EU, the UK, France, Germany were seen to have a recognized cache in international politics.

This analysis found a frequent perception of the EU's actions in the area of peace and security as weak and not expected to be strong. One reason for these low expectations was the perception that the EU lacked a security and foreign policy goal. A Japanese politician stated that the EU's 'diplomatic, security, and political policies are not unified'. An Indian newsmaker observed, 'We don't know what the EU foreign policy and security concerns are'. An Indian civil society respondent reflecting on the 2003 Iraq War and the divisions between the Member States argued that 'the EU has a long way to go in terms of common policy and a common outlook' noting the tendency among some European nations to 'hold onto their individual positions'. In short, respondents' system narrative suggested an understanding of a state-based system, with some states stronger than others. A hybrid actor like the EU offered only uncertainty.

Respondents in Japan were the most generous in their appraisal of the EU. In many interviews, Japanese respondents suggested that the EU will become increasingly important in the area of peace and security. For one Japanese politician, there is a growing realization among the Japanese people and policymakers of the EU's 'multi-dimensional role in military and security related areas'. Another politician said that, 'the EU is an increasingly important security actor'. The call for collaboration between the EU and Japan surfaced in many interviews and revealed a vision of a connected world when considering peace and security. Japanese respondents were also more receptive of the EU's peace-building know-how and experience: they saw the EU as a 'donor, or a community of donor nations...supporting peace-building in the world, including of course Africa and the Middle East and the Asia-Pacific region as well' (politician). Here, Japanese respondents revealed a different system narrative: one in which a hybrid, 'multidimensional' actor like the EU can play a role. For this respondent, these EU actions correspond to the key criteria - 'democracy and human rights'. The normative dimension of this response resonates with the EU's self-projection discussed above. These normative themes in the reception of the EU's system narrative were not apparent in China, India and South Korea. 
The EU's diplomatic role in the area of peace and security was also noted. Specifically, its peace narrative on this level is linked to economic interpretations. For an Indian politician, the EU is synonymous with 'trade exchange...Capital [moves] from one country to another country. Shifting of capital investment became also easier. And it is a factor to maintain...world peace.' For Indian respondents, then, the EU's contribution to an open global trading system makes peace and security more likely.

\section{Identity narrative}

The EU's peace and security narrative, in terms of the values and goals of the polity, took place on the identity level. When external elites commented on the EU internal effort to stop war on the European continent a positive perception prevailed - the norm of peace struck a chord. Occasionally, a counter-narrative formed - the story of 'Europe of war'. In these perceptions, Asian locations are contrasted with the EU and Asian states recognised as agents of peace around the world. For example, commenting on the situation in Libya, a Chinese businessperson notes, while 'the French advocate military solution, China stands for peaceful means'. Indian respondents also mentioned Europe as a cradle of world wars. For example, an Indian politician stated that for him the three spontaneous images of the EU are: 'wars...First World War or Second World War...all originated in Europe'. However, more typical was a businessperson from China who associated the EU with 'peace, no wars after World War II'. An Indian newsmaker echoed this idea when considering the EU's international leadership: 'It is one region of the world you do not expect war to break out'. In this regard, the EU is an example for Asia - 'if Europe could bury its differences of 300 years or 400 years of warfare, I am sure we could do that' (Indian media). A Japanese newsmaker commenting on the views on the EU as a global power said, 'There is harmony within [the EU], it is a peaceful and prosperous region'. A Korean civil society representative answering the same question states, it is amazing how these countries which...fought against each other approximately half a century ago came together and formed a political and economic union'.

Regarding other norms and values, only Japanese respondents frequently cited commonality in norms and values in matters of peace and security. A Japanese politician comments, 'its [EU] diplomacy, security, human rights, and democracy are very close to the values of Japan'. Another politician adds, 'both Japan and the EU...have similar values, and I think we will be good partners'. Moreover, Japanese elites were the most open to recognizing the EU as a 'normative power, setting the agenda and saying what is right and wrong' (Japanese politician). The EU's norm of regional integration is particularly valuable. A Japanese politician welcomes the EU as a 'frame of reference or a model for the Asia-Pacific in security community-building'.

Japan emerged after the World War II, committed to overcoming its defeat and remaking itself as a peaceful international actor, supporting the US-led politico-economic order. Like West Germany, Japan conceded unilateral autonomy over security policy in return for re-admittance into the West's political and economic order, as the basis for post-war recovery (Maull, 1990). It is perhaps this cultural experience, contemporaneous with Western Europe's economic and political recovery, that continues to define Japan's positive views towards Europe's political, social and economic model. 
Whilst the Korean sample featured the least visible links to the normative dimension in EU perceptions, Indian respondents were more prone to seeing normative divergences. The EU's understanding of security was perceived as conceptually different: the EU's 'concept of national security...can be called post-modern or post- sovereign...based on the idea of mutual interference, transparency and shared sovereignty. [This] is very foreign to Asia and...to India' (Indian media).

Chinese responses sometimes offered an identity narrative of China as norm-sender. For instance, a Chinese politician states, 'I think the two sides should...cultivate common values, build universal sense of security, economy and technology, which could ensure and keep China's influence on the EU'. A Chinese businessman states that in 'security interests and economic interests, [it is needed] to seek common ground'. Hence, we expect to find some alignment between the EU's and Chinese respondents' narratives, alongside Japan.

\section{Issue narrative}

The EU peace and security narrative on the issue level was visible in the four Asian countries. The EU was recognized as active on a number of issues in various international settings using a range of instruments. An Indian newsmaker noted, 'the EU is leading the peace talks, dispute settlements, safety measures and security issues in the Middle East.' His countryman from the same cohort cited EU peace-keeping and peace-making policies and actions when the EU was acting with the US and other countries in Afghanistan. Another common theme observed in Japan and India was recognition of the EU as a leader in non-traditional security, specifically energy and environmental security.

The representation of issue level narratives was location-specific; every location has its own peace and security priorities. Japanese respondents were the most positive and informed. This particular reception profile is captured in the comment that in peace and security matters 'Japan and the EU have a lot of similarities' (businessperson); that Japan is acting with the EU in peace operations ('I am working in the field of conflict management and peace operations...the EU is an increasingly important factor' (politician)). Commonality in policy positions was mentioned, for example, 'restraints on the military use of space and advocates for peaceful use' (businessperson).

Responding to the question about the EU as a global power, a Japanese politician said that the EU is trying to be a great power in military and economic terms - 'especially in the field of conflict management and peace operations. The EU has been trying to...make its voice heard internationally'. For one Japanese newsmaker, the three spontaneous images of the EU are 'Peace, peace-building and peace-maintenance'. Thus, great power identity depends on actions at an issue narrative level. Several Japan ese politicians recognized the EU in the context of the EU's involvement in peace-support operations - counter-piracy operations in Africa, the operations in Bosnia and Herzegovina and the DRC. EU perceptions were not always positive: 'With [EU] resources in some peacekeeping operations, the European EUFOR battle groups idea will be used, but that is marginal, not very significant, compared to [EU] normative power...That is the source of [EU] strength'. This reaction, with a strong normative stress, was given in the context of considering whether the EU is a great power. 
This analysis identifies several more critical reflections at this level of issue narrative. An Indian newsmaker noted, 'there are issues with the EU...because of the weapons we buy from European countries'. Whilst the EU embargoes weapons to certain states, these states get Europe-made weapons via third parties not embargoed by the EU.

In summary, the reception analysis investigated whether the EU and its Member States were credited as acting both internally, achieving peace within the EU, and externally far away from the EU's border, for instance, in Afghanistan and the DRC. EU peace and security actions in its own neighbourhood were not dominant in external perceptions circa 2012 (pre-Ukraine and pre-Syria crises). The external narratives framed EU actions from a mixed perspective. Most of the negative external visions were linked to the vision of the EU as an internally divided security actor of lesser capability and relevance to the four Asia locations than the US, Asian neighbours and powerful EU Member States. Narratives appear more positive and informed in Japan, a location which found commonality with EU norms and values.

\section{CONCLUDING DISCUSSION}

Despite its enduring legacy, the post-1945 EU peace narrative is contested. Commentators question its relevance to modern-day Europe. Our analysis of the peace and security narratives projected internally and externally by the Treaty of Lisbon demonstrated there is no single 'universal' peace narrative formulated and projected by the EU. The contemporary peace and security narrative is formed at the level of international system narrative - the EU as a unique supranational actor, an agent of peace and security in a changing world - both in the EU's immediate neighbourhood and in locations far from Europe's borders. The EU peace and security narrative also exists on the identity level - a normative identity vision where peace is a core norm and EU actions in peace and security spheres are guided by a set of norms stemming from its character. Finally, the level of EU issue peace and security narrative was also projected - the EU as a global peace-making, peace-building actor employing mechanisms of CFSP. The three levels in the EU peace and security narrative and the interactions between them indicate the EU's intention to be 'major global player' (Emerson et al., 2011).

Did respondents from the four Asian countries receive and interpret the EU in these terms? Only when they answered questions of three types. First, when asked whether the EU is perceived as an international leader and/or a global power, the concepts of leadership and power were complex and typically associated with interpretation of power in nation-state terms. The responses of external elites may indicate that the EU a complex supranational actor - is accorded a degree of actorness when viewed through the lens of peace and security by outsiders, particularly by Japanese respondents. Secondly, responses featuring references to the EU as a peace and security agent appeared when the respondents were generating (stereo)typical, spontaneous images of the EU. This finding suggests that 'peace' is a key feature in the external cognitive image of the EU, and forms part of the EU's conceptual recognition set outside its borders. Finally, a number of responses addressed the EU's relation with the location in question and the EU's relative importance to that location compared to other international actors. This reinforces our finding that perception of the EU's peace and security actions are somehow associated with the location in question - a higher relevance to locals' regionspecific narratives. 
The reception of the EU peace and security narrative in the four EU strategic partners in Asia revealed a complex construct on the system, identity and issue levels. Visibility of the narrative varies at these different levels. Asian narratives of the EU differed from the EU's self-formulated narratives in its foundational Treaty text. The most pronounced difference was in the lack of the references to norms and normative power on the systemic and issue levels in all locations but Japan (our initial prediction about perceptions in this case, informed by previous research, was supported). Importantly, Japan's positive and informed reception of the EU in normative terms was generated by Japan's selfperception of being a 'normative power of Asia' (relevant literature describes Japan as a 'normative foreign policy actor, at least in those regions and in those policy areas in which it has an active interest and presence (e.g. in its neighbourhood)' (Tocci, 2008, p.4). Thus, the original hypothesis was supported: the four powerful Asian actors have created their own image of the EU as a peace and security actor, negotiating the meaning of Europe's actions via narratives that reflect their own cultural filters, rather than accepting norms or images that the EU has produced. Whilst the EU is seen as an international actor in matters of peace and security, it is significant that the normative component of the EU's actions was largely neglected in three locations (India, China and Korea) and only marginally present in Japanese responses. It seems that for the four Asian powers, the EU is only of interest in selected areas.

Awareness of this convergence and divergence of self- and external narratives can be used to develop different emphases and priorities in the diplomatic dialogue on peace and security between the EU and its strategic partners in Asia. It points to contestation of the EU's normative ideas by the powers in Asia. This highlights a key payoff of the strategic narrative approach: knowledge of these diverging understandings of the sequence of events, character of actors, and desirable resolutions, can allow this reception analysis to feedback into (re)formation and (re)projection of EU narratives about itself and about external partners. We found contestation at each level of the EU peace narrative. The list of 'counter-narratives' included: the EU is a less powerful, coherent and therefore relevant actor than conventional state powers in an inter-national system (system level), Europe as different from an Asian 'normative power' and 'Europe of war' (identity level), and (on an issue level) an EU that either uses its policies to support war, or is incapable of producing policy to create a strong military corps or agreement between its Member States on matters of war and peace globally. Future studies could further explore reactions among Asian counterparts to the EU as a carrier of the norm of 'peace and security' - from adoption and adaption to resistance and rejection. The point is that this loop of formation/projection/reception can allow for more responsive EU communications where some "give" is politically feasible.

The EU's aspirations to become a major global actor were offset by the Eurozone crisis; the EU again turned inwards, jeopardizing its image and external recognition as a 'soft' and 'normative' power. The search for an appealing narrative became one of the EU's priorities. This is especially relevant for the EU's communication with Asia, as it strives to remain relevant in the region (Islam, 2010). Our analysis demonstrates that the narrative of the EU as a peace and security actor - on different levels - remains a 'story' recognised and received by the strategic global partners in varying, contested ways. It shows that the narrative on any level cannot be taken for granted. It will be contested, remixed and used to project the receivers' own narratives to reinforce their own identities, policy positions, and visions of how the international system should work. 
The 2016 EU Global Strategy redefines the EU's foreign policy narrative, projecting the EU as a more active, deliberate player in international affairs, in the face of mounting international challenges. It signals evolution of the EU's identity, issue and system narratives. Whilst retaining the EU's narrative of a peace and security, the elaboration of a system narrative is defined more by competition and regional orders. This may not align normatively with the EU, signalling a shift in how the EU both narrates its understanding of the emerging international order, and the EU's role within this changing landscape. 'Principled pragmatism' (EUGS, 2016. P.16) guided by a realistic assessment of the EU's strategic environment is stressed as a guiding tenet. This recognition of the EU's constrained agency as a global actor reflects our Asian respondents' perceptions. There is also a clear recognition that the rules-based international order, which the EUGS indicates is at the heart of the EU's system narrative, is under pressure from reformminded emerging powers such as China (EEAS, 2015: 2). Alignment with shifting narratives of the EU's Strategic Partners in Asia will be difficult. Making space for emerging powers such as China to have what they view as their rightful say in international affairs will involve challenges to the EU's identity, policy and system narratives, as these new powers seek to promote adaptation to the existing global order. This tallies with our Chinese respondents above who highlighted the emergence of a Chinese identity as a norm-sender. In the face of competing external economic and governance models, Brexit, and internal debates about the EU's direction, the absence of a new strategic narrative response to its challenges has triggered questions concerning whether the EU can continue to be influential globally.

Our own future research will investigate how the EU's narrative on peace and security is received by global partners over longer-time periods as well as short-term crises. Our study aimed to discover the existing narratives - projected and received - and to identify these narratives' convergence or divergence. Future research must aim to explain resonances and clashes. Above, we proposed a set of systemic, socio-historical and demographic factors, differentiated along the lines of location- and EU-specific and global factors. Future research must investigate what push-and-pull factors condition individuals to move towards one narrative understanding over another (cf. Moss and O'Loughlin, 2008). How can the work on narrative formation and projection at the institutional level connect to our exploration of reception and potential feedback? How are cultural filters sustained or contested in different social milieus? How do changing media ecologies enable elites and publics to debate normative and empirical dimensions of international affairs and how do different mainstream and social media allow actors to narrativise affairs in ways that engage and even impact upon others? Finally, policyrelevant research must identify points of undiscovered convergence or alignment between the narratives held by the EU and its strategic partners as a basis for further cooperation. Understanding of the narrative negotiation - rather than transmission of EU narratives - would provide EU leaders with a more nuanced and effective approach to narrative practices.

\section{REFERENCES}


Björkdahl, A., N. Chaban, A. Masselot, J. Leslie (eds.) (2015) Importing EU Norms: Conceptual Framework and Empirical Findings, NY, Heidelberg: Springer.

Burke, K. (1957) The Philosophy of Literary Form. New York: Vintage.

Chaban, N. and M. Holland (2015) "EU External Perceptions: from innovation to an established field of study", in A. Aarstad et al. (ed.) Handbook of European Foreign Policy, NY/London/New Delhi: Sage, 672-686.

Chaban, N. and M. Holland (eds.) (2014) Communicating Europe in the Times of Crisis: External Perceptions of the European Union, Houndmills: Palgrave-McMillan.

Chaban, N. and Magdalina, A.-M. (2014) 'External perceptions of the EU during the Eurozone sovereign debt crisis', EFAR, 19(2):195-220.

Della Sala, V. (2010). 'Political myth, mythology and the European Union'. JCMS, 48(1), 1-19.

Disaggregating Chinese perceptions of the EU, http://cordis.europa.eu/result/rcn/54186 en.html

Elgström, O. and N. Chaban (2015) "To study external perceptions of the EU: A conceptual approach", in M. Muller and V. Bachmann (eds.) Looking in from the Outside: Perceptions of the EU in Eastern Europe and Sub-Saharan Africa, Basingstoke: Palgrave-McMillan, 17-33.

Emerson, M., Balfour, R., Corthaut, T., Kaczyński, M., Renard, T., and J. Wouters, (2011) Upgrading the EU's Role as Global Actor: Institutions, Law and the Restructuring of European Diplomacy, Brussels: Centre for European Policy Studies.

EuroBroadMap, http://www.eurobroadmap.eu/

European External Action Service, 'Asia', http://www.eeas.europa.eu/asia/index en.htm

European External Action Service (2015) Strategic Review: The European Union in a Changing Global Environment. https://europa.eu/globalstrategy/en/strategic-review-european-unionchanging-global-environment

Garton Ash, T. (2012) 'The Crisis of Europe, How the Union Came Together and Why It's Falling Apart', Foreign Affairs, https://www.foreignaffairs.com/articles/europe/2012-08-16/crisiseurope

Heisbourg, F. (2001) 'Europe's Strategic Ambitions: The Limits of Ambiguity', Survival 42(2): 515.

Islam, S. (2010), 'A Seat for the EU at East Asia's Top Table', EUObserver, 11 November, http://euobserver.com/opinion/31241.

Jain, R. K. and S. Pandey (2010) 'The European Union in the Eyes of India', Asia-Europe Journal, 8(2), 193-210.

Jain, R. K. and S. Pandey (2013) 'Indian Elites and the EU as a Normative Power', Baltic Journal of European Studies, 3(3), 105-126.

Kaldor, M., M. Martin and S. Selchow (2007) 'Human security: a new strategic narrative for Europe.' International Affairs 83(2): 273-288.

Kinnvall, C. (1995) Cultural Diffusion and Political Learning: The Democratization of China, Lund: Lund University Press.

Lacroix, J. and K. Nicolaïdis (2010) European Stories: Intellectual Debates on Europe in National Context. Oxford: Oxford University Press.

Lisbonne-de Vergeron, K. (2011) Chinese and Indian Views of Europe since the Crisis: new perspectives from the emerging Asian giants, http://www.kas.de/wf/doc/kas 29944-15222-30.pdf?120118092530

Lisbonne-de Vergeron, K. (2006) Contemporary Indian views of Europe. London: Chatham House, http://www.chathamhouse.org/publications/papers/view/

Lisbonne-de Vergeron, K. (2007) Contemporary Chinese views of Europe. London: Chatham House, http://www.comw.org/cmp/fulltext/0711vergeron.pdf

Lucarelli, S. (2014) 'Seen from the outside: the state of the art on the external image of the EU'. Journal of European Integration, 36: 1-16.

Lucarelli, S. and Fioramonti, L. (eds) (2009) External Perceptions of the European Union as a Global Actor. New York: Routledge. 
Manners, I. (2002) 'Normative Power Europe: A Contradiction in Terms?', JCMS 40(2), 235-58.

Manners, I. and Murray, P. (2016). "The end of a noble narrative? European integration narratives after the Nobel Peace Prize'. JCMS, 54(1), 185-202.

Maull, H.W. (1990) 'Germany and Japan: The New Civilian Powers', Foreign Affairs 69(5), 91-106. Mills, C.W. (1956) The Power Elite. New York: Oxford University Press.

Mishra, A. (2009), 'Strategic Asia: Region Must Follow Europe's Lead down the Rocky Road to Union', The Jakarta Globe, 16 December, http://thejakartaglobe.beritasatu.com/archive/strategic-asia-region-must-follow-europeslead-down-the-rocky-road-to-union/.

Miskimmon, A., B. O'Loughlin and L. Roselle (2013) Strategic Narratives: Communication Power and the New World Order. New York: Routledge

Morgenthau, H.J. (1965) Vietnam: shadow and substance. New York Review of Books, 16 September.

Moss, G., and O'Loughlin, B. (2008). Convincing claims: Representation and democracy in post9/11 Britain. Political Studies, 56(3), 705-24.

O'Loughlin, B. (2011). Images as weapons of war: representation, mediation and interpretation. Review of International Studies, 37(1), 71-91.

Ortega, M. (ed.) (2004) Global Views on the European Union, Chaillot Paper, 71.

Oshiba, R. (2012) 'A Japanese view of the EU'. Perspective: Review of International Affairs, 20(2), 103-128.

Pardo, S. Normative Power Europe Meets Israel: Perceptions and Realities, Lanham MD: Lexington Books.

Park, S. and Yoon, S.-W. (2010) EU perceptions through the FTA lens: main results of interviews among the Korean 'elites', Asia-Europe Journal, 8, 177-191.

Park, S. and Yoon, S.-W. (2015) The EU in the Views of Korean 'Elites': New Findings and Some Lessons, Asia-Europe Journal, 13(1)

PPMI/NCRE/NFG (2015) Analysis of EU Perception of the EU and EU's Policy of the EU, http://ec.europa.eu/dgs/fpi/showcases/eu perceptions study en.htm

Rhodes, C. (ed.) (1998) The European Union in the World Community, Boulder \& London: Lynne Rienuer.

Shambaugh, D., E. Sandschneider and H. Zhou (eds.) (2008) China-Europe Relations: Perceptions, Politics and Prospects. London: Routledge.

Shenhav, S. R. (2006). Political narratives and political reality. International Political Science Review, 27(3): 245-262.

Stumbaum, M.-B., Gippner, O., Lutz, A., Mohan, G., Zhao, J. (2015) Does Europe Matter? EU as a Security Actor in the Asian Century, NFG Final Report, FU Berlin.

Tocci, N. (ed.) (2008) Who is a normative foreign policy actor? The European Union and its Global Partners, Centre for European Policy Studies, Brussels

Treaty of Lisbon (2009) http://eur-lex.europa.eu/legalcontent/EN/TXT/PDF/?uri=0J:C:2007:306:FULL\&from=EN

Tsuruoka, M. (2011) 'Defining Europe's Strategic Interests in Asia', STUDIA DIPLOMATICA, LXIV: 95-107.

Tsuruoka, M. (2008) Expectations Deficit' in EU-Japan Relations: Why EU-Japan Partnership Cannot Flourish', Current Politics and Economics of Asia, 17-1.

Zeng, J. and S. Breslin (2016) 'China's new type of great power relationship: moving toward "G2" with Chinese characteristics?' International Affairs, 92(4).

Zhang, L. (2011) News Media and EU-China Relations, Basingstoke: Palgrave-Macmillan.

Zhou, H. A (2007) Chinese perspective on Lisbon Strategy. Asia-Europe Journal, 5(3): 357-365. 
i Interviews were conducted by: Professor Paul Bacon (Waseda University, Japan); Dr Shreya Pandey (Central University of Jharkhand, India); Dr Sung-Won Yoon (University of Suwon, Korea); and a team of post-graduates led by Dr LAI Suet-Yi (all of Tshinghua University, China).

ii That such presentation of qualitative analysis can contribute to IR scholarship is evident from O'Loughlin's three-year study of 239 individuals' perceptions of security (O'Loughlin, 2011; Moss and O'Loughlin, 2008).

iii Anonymity of the respondents was warranted by the interview protocol. 